these strategies, both prenatal and postnatal, can have a positive impact on child growth.

Moving forward, researchers in the field must incorporate all point to their studies. The conclusion of study by Sjarif et al $^{1}$ need to be furtherly examined by considering these complexities and using better study design to generate more acceptable conclusion.

\section{Irma Hidayana}

Independent consultant

ih2296@tc.columbia.edu

Tan Shot Yen

Community Nutrition, Dr. Tan \& Remanlay Institute, Tangerang Selatan, Banten, Indonesia

Dian Hadihardjono

Nutrition Program, Helen Keller International

No potential conflict of interest relevant to this letter was reported.

1. Sjarif DR, Yuliarti K, Iskandar WJ. Daily consumption of growingup milk is associated with less stunting among Indonesian toddlers. Med J Indones. 2019;28(1):70-6.

2. Codex Alimentarius Commission. Standard for infant formula and formulas for special medical purposes intended for infants: Codex STAN 72-1981. Codex Alimentarius Commission. 2015.

3. Thorne-Lyman A, Spiegelman D, Fawzi WW. Is the strength of association between indicators of dietary quality and the nutritional status of children being underestimated? Matern Child Nutr. 2014;10(1):159-60.

4. de Onis M, Branca F. Childhood stunting: a global perspective. Matern Child Nutr. 2016;12 Suppl 1(Suppl 1):12-26.

5. Torlesse H, Cronin AA, Sebayang SK, Nandy R. Determinants of stunting in Indonesian children: evidence from a cross-sectional survey indicate a prominent role for the water, sanitation and hygiene sector in stunting reduction. BMC Public Health. 2016;16:669.

https://doi.org/10.13181/mji.cor.204566

Check for updates

THE AUTHORS REPLY: We thank the correspondents for their concerns. The World Health Organization defines stunting as short-stature (stunted) due to chronic malnutrition. Stunting is used as a marker of chronic undernutrition (energy and protein deficiency) that further impairs brain development (decreased intelligence up to 13.1 points) ${ }^{1}$ and alters hormonal balance triggering degenerative diseases. Therefore, numerous preventive measures are important, especially those affecting linear growth.

Among type II nutrients, which are energy, essentials amino acids, and several important micronutrients, a meta-analysis showed protein as the most important factor associated with increased linear growth, but not multiple micronutrient supplementation. The latter only led to an increase of $0.09 \mathrm{~cm}$ per year, which was far from the expected increase of $25 \mathrm{~cm}$ in the first year of life and $10 \mathrm{~cm}$ per year until the child reached 5 years old. ${ }^{2}$ We attempted to elaborate on the role of animal protein as one of the key nutrients to promote linear growth. One of the most common animal proteins is milk, whose intake is positively associated with serum insulin-like growth factor 1 concentrations and height. ${ }^{3}$ Therefore, in the present study, it was aimed to evaluate the role of animal protein, especially milk as it has a high biological value among other protein sources in terms of linear growth.

Based on this clinical background, we used secondary data from the Ironcheq study, which comprised a simple dietary questionnaire of an animal protein food source that contains iron, which are growing-up formula (the term used by the Indonesian Food and Drugs Administration to address formula for toddlers), eggs, and meat products. The purpose was to hint community health workers whether a child is suspected of iron deficiency and should have a further assessment by a pediatrician. The subjects were 300 healthy (examined by a pediatrician) toddlers ranging from 1 to 3 years old. The inflammation factors were identified by clinical and laboratory examinations. The limitations of the study using secondary data was clearly described in the published article. Meanwhile, there is an ethical concern for conducting randomized controlled clinical trial of stunted toddlers by giving milk compared to placebo.

Next, regarding the issue of the screening tool, the Ironcheq questionnaire was mainly designed as a community screening tool that is simple but yields good diagnostic value. Nearly all screening tools use a scoring system and there is no questionnaire screening involves quantitative analysis. However, an analysis using 3-day food record was also done in the Ironcheq study. ${ }^{4}$ Based on the food record, the proportion of children not consuming any GUM was higher in children with stunting (41.5\%) than without stunting (19.9\%).

Furthermore, the study's subjects had a narrow age range ( 1 to 3 years old). Thus, the breastmilk intake may be similar since, in toddlerhood, nutritious family food is encouraged as the main nutritional source and not predominantly by breastfeeding. 5 Therefore, quantitative analysis of breastmilk contribution in this narrow age group and with relatively similar breastfeeding patterns is irrelevant.

We agree that wealth may be a potential bias for this result. However, we recruited all the subjects from an integrated service post (Posyandu) representing similar socio-economical background. The variation will 
come wider when the subjects' recruitment is variedly done in private clinics or large hospitals. Moreover, socio-economic factors have been taken into account and included in the analysis in Table 2.

Regarding the sanitation issue, recent data from a big and robust water, sanitation, and hygiene study, Humphrey et $\mathrm{al}^{6}$ found that improved pit latrines, handwashing stations, and water chlorination unlikely improve child growth. This means implementing those interventions in addition to complementary feeding unlikely improves child growth more than complementary feeding alone.

In the end, the result of this study may give an alternative approach to prevent undernutrition (especially energy and protein). It is important to catch up golden period of brain growth before 2 years old. The report from 79 countries with the average stunting prevalence of $26 \%$ stated that for every $10 \%$ increase in stunting, the proportion of children finishing primary school dropped by $7.9 \%{ }^{1}$ The high stunting prevalence of under-fives in Indonesia posed a critical situation for the future of human resources. We should vigorously act and seek alternative preventive measures to save the future of our nation.
Damayanti Rusli Sjarif

Klara Yuliarti

William Jayadi Iskandar

Department of Child Health, Faculty of Medicine, Universitas Indonesia, Cipto Mangunkusumo Hospital, Jakarta

Email: ukk.npm.idai@gmail.com

1. Grantham-McGregor S. A review of studies of the effect of severe malnutrition on mental development. J Nutr. 1995;125(8 Suppl):2233S-8S.

2. Ramakrishnan U, Nguyen P, Martorell R. Effects of micronutrients on growth of children under $5 \mathrm{y}$ of age: metaanalyses of single and multiple nutrient interventions. Am J Clin Nutr. 2009;89(1):191-203.

3. Hoppe C, Udam TR, Lauritzen L, Mølgaard C, Juul A, Michaelsen KF. Animal protein intake, serum insulin-like growth factor I, and growth in healthy 2.5-y-old Danish children. Am J Clin Nutr. 2004;80(2):447-52.

4. Sjarif DR, Tjia S, Yuliarti K, Kekalih A. Ironcheq questionnaire as a first step screening tool for detecting iron deficiency in toddler. J Pediatr Gastroenterol Nutr. 2015;60 Suppl (1):839.

5. Dewey KG, Brown KH. Update on technical issues concerning complementary feeding of young children in developing countries and implications for intervention programs. Food Nutr Bull. 2003;24(1):5-28.

6. Humphrey JH, Mbuya MN, Ntozini R, Moulton LH, Stoltzfus RJ, Tavengwa NV, et al. Independent and combined effects of improved water, sanitation, and hygiene, and improved complementary feeding, on child stunting and anaemia in rural Zimbabwe: a cluster-randomised trial. Lancet Glob Health. 2019;7(1):132-47.

https://doi.org/10.13181/mji.cor.204630
Check for updates 